ETNIK : Jurnal Ekonomi - Teknik

ISSN: 2808-6694 (Online);2808-7291 (Print)

Jurnal Homepage https://etnik.rifainstitute.com

\title{
Pengaruh Atraksi, Aksesibilitas, Amenitas dan Kualitas Pelayanan Terhadap Minat Kunjungan Ulang Wisatawan di Pulau Kumala Kabupaten Kutai Kartanegara
}

\author{
Riri Febria Dita, Muhammad Zaini
}

Universitas Mulawarman

\section{Informasi Artikel}

Histori Artikel:

Diterima 08 January 2022

Direvisi 15 January $\mathbf{2 0 2 2}$

Diterbitkan 20 January 2022

Email Author:

ririfebriadita@gmail.com mzaini@fisip.unmul.ac.id

\begin{abstract}
The tourism industry in Indonesia continues to grow along with the development of technology, transportation, and information. So that companies or tourism business actors must pay attention to tourism marketing by promoting service products and service quality in these tourist destinations. Kumala Island is a leading tourist attraction in Kutai Kartanegara Regency. The purpose of this study was to determine the effect of attractions, accessibility, amenities, and quality of service on the interest in repeat visits to Kumala Island, Kutai Kartanegara Regency. This study uses primary data by distributing questionnaires. The population in this study are visitors who have visited Kumala Island, with a sample of 100 respondents using thetechnique Accidental Sampling. The data analysis of this research uses multiple linear analysis using SPSS version 25.The results of this study prove that the Attraction variable partially has a positive and significant effect on Tourist Revisit Interest. Then the accessibility variable partially has a positive and significant effect on Tourist Revisit Interests. The Amenity variable partially has a positive and significant effect on Tourist Revisit Interests. Furthermore, the service quality variable partially has no positive and insignificant effect on Tourist Revisit Interests. Furthermore, simultaneously attractions, accessibility, amenities and quality of service partially have a positive and significant effect on Tourist Revisit Interests. The conclusion of this study explains that partially between the variables of attraction, accessibility, amenity have a positive and significant influence on the interest of repeat tourists. While the quality of service does not have a positive and insignificant effect on the interest of repeat tourists, but simultaneously the variables of attraction, accessibility, amenity and service quality have a positive and significant influence on the interest of repeat tourists.
\end{abstract}

Keywords - Attractions, Accessibility, Amenity, Quality of Service, Interest in Repeat Visits

ABSTRAK 
Industri pariwisata di Indonesia terus berkembang seiring dengan perkembangan teknologi, transportasi, dan informasi. Sehingga Perusahaan atau pelaku usaha pariwisata harus memperhatikan pemasaran pariwisata dengan mempromosikan produk jasa maupun kualitas pelayanan di destinasi wisata tersebut. Pulau Kumala merupakan wisata unggulan di Kabupaten Kutai Kartanegara. Tujuan penelitian ini adalah untuk mengetahui pengaruh atraksi, aksesibilitas, amenitas, dan kualitas pelayanan terhadap minat kunjungan ulang di Pulau Kumala Kabupaten Kutai Kartanegara. Penelitian ini menggunakan data primer dengan penyebaran kuesioner. Populasi dalam penelitian ini adalah pengunjung yang pernah berkunjung ke Pulau Kumala, dengan jumlah sampel 100 responden menggunakan teknik Accidental Sampling. Analisis data penelitian ini menggunakan analisis linear berganda menggunakan SPSS versi 25. Hasil penelitian ini membuktikan bahwa variabel Atraksi secara parsial berpengaruh positif dan signifikan terhadap Minat Kunjungan Ulang Wisatawan. Kemudian variabel aksesibilitas secara parsial berpengaruh positif dan signifikan terhadap Minat Kunjungan Ulang Wisatawan. Variabel Amenitas secara parsial berpengaruh positif dan signifikan terhadap Minat Kunjungan Ulang Wisatawan. Selanjutnya untuk variabel kualitas pelayanan secara parsial tidak berpengaruh positif dan tidak signifikan terhadap Minat Kunjungan Ulang Wisatawan. Selanjutnya secara simultan atraksi, aksesibilitas, amenitas dan kualitas pelayanan secara parsial berpengaruh positif dan signifikan terhadap Minat Kunjungan Ulang Wisatawan. Kesimpulan dari penelitian ini menerangkan bahwa secara parsial antar variabel atraksi, aksesibilitas, amenitas memiliki pengaruh positif dan signifikan terhap Minat Kunjungan Ulang Wisatawan. Sedangkan kualitas pelayanan tidak berpengaruh positif dan tidak signifikan terhadap Minat Kunjungan Ulang Wisatawan, tapi secara simultan antar variabel atraksi, aksesibilitas, amenitas dan kualitas pelayanan memiliki pengaruh positif dan dan signifikan terhadap Minat Kunjungan Ulang Wisatawan

Kata Kunci - Atraksi, Aksesibilitas, Amenitas, Kualitas Pelayanan, Minat Kunjungan Ulang

\section{PENDAHULUAN}

Industri pariwisata di Indonesia terus berkembang seiring dengan perkembangan teknologi, transportasi, dan informasi, yang ditandai dengan terus bertambahnya jumlah destinasi wisata yang ada di Indonesia. Pertumbuhan industri pariwisata semakin ketat persaingan, yang menuntut perusahaan atau pelaku usaha memiliki keunggulan bersaing. Perusahaan atau pelaku usaha pariwisata harus memperhatikan pemasaran pariwisata yang sangat berbeda dengan pemasaran produk pada umumnya, yang mana pemasaran pariwisata mempromosikan jasa yang ada di destinasi wisata tersebut.

Perusahaan atau pelaku usaha pariwisata juga harus memperhatikan kualitas produk pariwisata, yang merupakan kemampuan suatu perusahaan untuk memberikan identitas atau ciri pada setiap produknya sehingga konsumen dapat mengenali produk tersebut (Fajri, 2018). Kualitas 
Produk tidak hanya berupa barang saja tetapi bisa berupa jasa, seperti yang ada di kualitas produk jasa pariwisata mempunyai tiga komponen, yaitu Attaraction (atraksi), Accessibility (aksesibilitas), dan Amenity (amenitas) (Kurniansah, 2016).

Selain kualitas produk pariwisata, penyedia layanan jasa wisata juga harus memperhatikan kualitas layanan. Kualitas pelayanan merupakan upaya untuk memenuhi kebutuhan dan harapan wisatawan serta memberikan ketepatan dalam menyeimbangkan harapan wisatawan (Isabari et al., 2021). Kualitas pelayanan mempunyai lima prinsip dimensi yaitu Reliability (reliabilitas), Responsinveness (responsive), Assurance (kepastian atau jaminan), Empathy (empati), dan Tangibles (nyata) (Guspul, 2014). Perusahaan atau pelaku usaha dengan meningkatkan kualitas produk dan kualitas pelayanan dalam suatu tempat wisata berpengaruh citra wisata, sehingga wisatawan yang pernah berkunjung akan kembali dan merekomendasikan tempat wisata tersebut.

Kabupaten Kutai Kartanegara merupakan salah satu kabupaten yang ada di Kalimantan Timur mempunyai sektor pariwisata unggulan dengan berbagai peninggalan budaya pada masa kerajaan Kutai yang memiliki daya tarik tersendiri bagi wisatawan. Pariwisata yang ada di Kabupaten mempunyai dua pesona yaitu pesona budaya dan pesona alam. Salah satu destinasi wisata yang ada di Kabupaten Kutai Kartanegara ialah Pulau Kumala. Pulau Kumala merupakan pulau kecil ditengah Sungai Mahakam. Pulau kecil ini memiliki daratan seluas 76 hektar ini dirancang pemerintah daerah setempat untuk menjadi sebuah tempat wisata rekreasi yang arsitekturnya merupakan perpanduan antara teknologi modern dan budaya tradisional. Selain itu, Pulau Kumala menyediakan tempat yang bisa dilihat pengunjung yaitu Rumah Lamin (rumah suku Dayak) serta bangunan candi bernama Pura Pasak Pulau yang merupakan salah satu tempat ibadah penganut agama Hindu, dan patung Lembuswana terletak di ujung pulau yang menghadap kearah jembatan Kutai Kartanegara.

Seiring waktu Pulau Kumala mengalami penurunan Kunjungan Wisatawan setiap tahunnya. Pada Tahun 2017, Data Kunjungan Wisatawan Nusantara di Pulau Kumala memperoleh 389,234 wisatawan berkunjung, mempunyai angka yang cukup baik. Selanjutnya pada tahun 2018 mengalami penurunan, yaitu memperoleh 287,595 dan tahun 2019 mengalami penurunan yaitu 173, 905. Penurunan setiap tahunnya mengalami beberapa faktor, yang menjadi penghambat di tempat wisata ini, yaitu salah satu tempat penginapan atau cottage yang belum dikelola dengan baik, fasilitas yang belum memadai, kurangnya tingkat keamanan adanya aksi premanisme yang meminta dan memaksa pengunjung untuk menggunakan jasa penyewaan sepeda maupun sepeda motor listrik, serta tingkat keindahan alam yang ada di Pulau Kumala belum tertata rapi karena masih banyak rumput-rumput liar yang tumbuh.

\section{METODE}

Penelitian ini berfokus pada kajian tentang pariwisata, yang berhubungan dengan Atraksi, Aksesibilitas, Amenitas, Kualitas Pelayanan, dan Minat Kunjungan Ulang Wisatawan. Penelitian ini menggunakan jenis asosiatif. Populasi dalam penelitian ini adalah pengunjung yang pernah berkunjung ke Pulau Kumala, dengan jumlah sampel 100 responden. Sampel penelitian ditetapkan dengan menggunakan rumus Lemeshow. Teknik Sampling yang digunakan yaitu nonprobability sampling dengan teknik Accidental Sampling, yaitu siapa saja yang secara kebetulan bertemu dengan peneliti dapat digunakan sebagai sampel, bila dipandang orang yang kebetulan ditemui itu cocok sebagai sumber data" (Gofur, 2019). Pengumpulan data pada penelitian ini menggunakan kuesioner dan observasi. Teknik analisis data menggunakan Uji Validitas, Uji Reliabilitas, Uji 
Asumsi Klasik, Analisis Regresi Linear Berganda, dan Pengujian Hipotesis.

\section{HASIL DAN PEMBAHASAN}

\section{Hasil Penelitian}

\section{Uji Validitas}

Tabel 1. Hasil Uji Validitas

\begin{tabular}{|c|c|c|c|c|}
\hline Variabel & Kode Item & R hitung & $R$ tabel & Keterangan \\
\hline \multirow[t]{4}{*}{ Atraksi (X1) } & $\mathrm{X} 1.1$ & 0,515 & 0,195 & VALID \\
\hline & $\mathrm{X} 1.2$ & 0,715 & 0,195 & VALID \\
\hline & $\mathrm{X} 1.3$ & 0,724 & 0,195 & VALID \\
\hline & $\mathrm{X} 1.4$ & 0,826 & 0,195 & VALID \\
\hline \multirow[t]{5}{*}{ Aksesibilitas(X2) } & $\mathrm{X} 2.1$ & 0,633 & 0,195 & VALID \\
\hline & $\mathrm{X} 2.2$ & 0,703 & 0,195 & VALID \\
\hline & $\mathrm{X} 2.3$ & 0,687 & 0,195 & VALID \\
\hline & $\mathrm{X} 2.4$ & 0,802 & 0,195 & VALID \\
\hline & $\mathrm{X} 2.5$ & 0,675 & 0,195 & VALID \\
\hline \multirow[t]{9}{*}{ Amenitas (X3) } & $\mathrm{X} 3.1$ & 0,519 & 0,195 & VALID \\
\hline & $\mathrm{X} 3.2$ & 0,655 & 0,195 & VALID \\
\hline & X3.3 & 0,600 & 0,195 & VALID \\
\hline & $\mathrm{X} 3.4$ & 0,593 & 0,195 & VALID \\
\hline & X3.5 & 0,643 & 0,195 & VALID \\
\hline & X3.6 & 0,648 & 0,195 & VALID \\
\hline & $\mathrm{X} 3.7$ & 0,701 & 0,195 & VALID \\
\hline & $\mathrm{X} 3.8$ & 0,664 & 0,195 & VALID \\
\hline & X3.9 & 0,632 & 0,195 & VALID \\
\hline \multirow{10}{*}{$\begin{array}{l}\text { Kualitas Pelayanan } \\
\text { (X4) }\end{array}$} & $\mathrm{X} 4.1$ & 0,786 & 0,195 & VALID \\
\hline & $\mathrm{X} 4.2$ & 0,764 & 0,195 & VALID \\
\hline & $\mathrm{X} 4.3$ & 0,727 & 0,195 & VALID \\
\hline & $\mathrm{X} 4.4$ & 0,68 & 0,195 & VALID \\
\hline & $\mathrm{X} 4.5$ & 0,716 & 0,195 & VALID \\
\hline & $\mathrm{X} 4.6$ & 0,743 & 0,195 & VALID \\
\hline & $\mathrm{X} 4.7$ & 0,696 & 0,195 & VALID \\
\hline & $\mathrm{X} 4.8$ & 0,700 & 0,195 & VALID \\
\hline & X4.9 & 0,613 & 0,195 & VALID \\
\hline & $\mathrm{X} 4.10$ & 0,701 & 0,195 & VALID \\
\hline \multirow{8}{*}{$\begin{array}{c}\text { Minat Kunjungan } \\
\text { Ulang Wisatawan } \\
\text { (Y) }\end{array}$} & Y.1 & 0,545 & 0,195 & VALID \\
\hline & Y.2 & 0,499 & 0,195 & VALID \\
\hline & Y.3 & 0,348 & 0,195 & VALID \\
\hline & Y.4 & 0,706 & 0,195 & VALID \\
\hline & Y.5 & 0,702 & 0,195 & VALID \\
\hline & Y.6 & 0,780 & 0,195 & VALID \\
\hline & Y.7 & 0,753 & 0,195 & VALID \\
\hline & Y.8 & 0,705 & 0,195 & VALID \\
\hline
\end{tabular}




\begin{tabular}{|l|c|c|c|c|}
\hline & Y.9 & 0,768 & 0,195 & VALID \\
\cline { 2 - 5 } & Y.10 & 0,839 & 0,195 & VALID \\
\cline { 2 - 5 } & Y.11 & 0,836 & 0,195 & VALID \\
\hline
\end{tabular}

Sumber : Hasil Pengolahan Data SPSS (versi 25), 2021

Pada tabel 1 di atas dapat dilihat bahwa dari setiap item pernyataan diperoleh $r$ hitung lebih besar dari $\mathrm{r}$ tabel $=0,195$, maka setiap item diatas dinyatakan valid dan dengan demikian data yang diperoleh layak untuk dianalisis selanjutnya menggunakan analisis regresi.

\section{Uji Reliabilitas}

Tabel 1. Hasil Pengujian Uji Reliabilitas

\begin{tabular}{|c|c|c|c|c|}
\hline No & Variabel & Cronbach's Alpha & N of Items & Keterangan \\
\hline 1 & X1 & 0,648 & 4 & Reliabel \\
\hline 2 & X2 & 0,742 & 5 & Reliabel \\
\hline 3 & X3 & 0,830 & 9 & Reliabel \\
\hline 4 & X4 & 0,892 & 10 & Reliabel \\
\hline 5 & Y & 0,882 & 11 & Reliabel \\
\hline
\end{tabular}

Sumber : Hasil Pengolahan Data SPSS ( versi 25), 2021

Dari tabel 2 diatas menunjukkan bahwa nilai cronbach's alpha X1 sebesar 0,648 > 0,60, X2 sebesar $0,742>0,60, \mathrm{X} 3$ sebesar 0,830 > 0,60, X4 sebesar 0,892 > 0,60, dan Y sebesar 0,882 > 0,60, yang artinya instrument atau item-item dalam penelitian ini reliabel untuk mengukur variabel Atraksi, Aksesibilitas, Amenitas, dan Kualitas Pelayanan terhadap Minat Kunjungan Ulang Wisatawan.

\section{Uji Asumsi Klasik}

1. Uji Normalitas

Tabel 2. Uji Normalitas

One-Sample Kolmogorov-Smirnov Test

\begin{tabular}{llr} 
& & $\begin{array}{c}\text { Unstandardized } \\
\text { Residual }\end{array}$ \\
\hline $\mathrm{N}$ & & 100 \\
\hline Normal Parameters ${ }^{\mathrm{a}, \mathrm{b}}$ & Mean & .0000000 \\
\cline { 2 - 3 } & Std. Deviation & 3.27174913 \\
\hline Most Extreme Differences & Absolute & .066 \\
\cline { 2 - 3 } & Positive & .061 \\
\cline { 2 - 3 } & Negative & -.066 \\
\hline Test Statistic & & .066 \\
\hline Asymp. Sig. (2-tailed) & & $.200^{\mathrm{c}, \mathrm{d}}$ \\
\hline
\end{tabular}

Sumber Hasil Pengolahan Data SPSS (versi 25), 2021

Nilai signifikan pada tabel 3 One-Sampe Kolmogorov-Smirniov Test untuk Atraksi, Aksesibilitas, Amenitas, Kualitas Pelayanan, Minat Kunjungan Ulang Wisatawan adalah 0,200> 0,05 yang artinya data berdistribusi normal.

2. Uji Multikolinieritas 


\section{Tabel 4. Hasil Uji Multikolinieritas}

\begin{tabular}{|c|c|c|c|c|c|c|c|}
\hline \multicolumn{8}{|c|}{ Coefficients: } \\
\hline \multirow[b]{2}{*}{ Model } & \multicolumn{2}{|c|}{$\begin{array}{l}\text { Unstandardized } \\
\text { Coefficients }\end{array}$} & \multirow{2}{*}{$\begin{array}{c}\text { Standardized } \\
\text { Coefficients } \\
\text { Beta }\end{array}$} & \multirow[b]{2}{*}{$\mathrm{t}$} & \multirow[b]{2}{*}{ Sig. } & \multicolumn{2}{|c|}{$\begin{array}{l}\text { Collinearity } \\
\text { Statistics }\end{array}$} \\
\hline & B & Std. Error & & & & Tolerance & VIF \\
\hline (Constant) & 3.720 & 2.895 & & 1.285 & .202 & & \\
\hline Atraksia & 1.142 & .234 & .410 & 4.872 & .000 & .654 & 1.529 \\
\hline Aksessibilitas & .417 & .205 & .197 & 2.033 & .045 & .494 & 2.023 \\
\hline Amenitas & .310 & .114 & .277 & 2.733 & .007 & .450 & 2.224 \\
\hline Kualitas Pelaxanan & .058 & .119 & .051 & .487 & .628 & .419 & 2.384 \\
\hline
\end{tabular}

Sumber : Hasil Pengolahan Data SPSS (versi 25), 2021

Berdasarkan tabel 4 Diatas diketahui bahwa nilai VIF adalah 1,529 (variabel atraksi), 2.023 (variabel aksesibilitas), 2.224 (variabel amenitas), dan 2.384 (variabel kualitas pelayanan). Hasil ini berarti variabel terbebas dari asumsi klasik multikolinieritas karena hasilnya lebih kecil dari 10. Nilai tolerance pada variabel atraksi $(0,654>0,10)$, variabel aksesibilitas $(0,494>0,10)$, variabel amenitas $(0,450>0,10)$, variabel kualitas pelayanan $(0,419>0,10)$, maka data tersebut tidak terjadi multikolinieritas.

3. Uji Heteroskedastisitas

\section{Gambar 1. Hasil Uji Heteroskedastisitas}

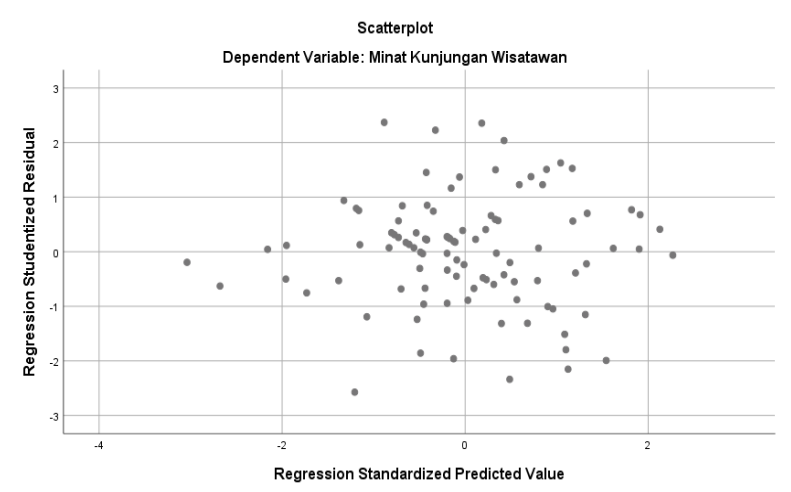

Sumber : Hasil Pengolahan Data SPSS (versi 25), 2021

Grafik Scatter plot di atas menunjukkan bahwa titik-titik pada diagram tidak membentuk pola yang jelas. Titik-titik menyebar secara acak serta tersebar dengan baik di atas maupun dibawah angka 0 . Sehingga dapat di ambil kesimpulan bahwa tidak terjadi masalah heteroskedastisitas pada model regresi.

\section{Analisis Regresi Linear Berganda}

Tabel 3. Analisis Regresi Linear Berganda

\begin{tabular}{|c|c|c|c|c|c|}
\hline \multirow[b]{3}{*}{ Model } & \multicolumn{2}{|c|}{ Coefficients $^{a}$} & \multicolumn{3}{|c|}{ (a) } \\
\hline & \multicolumn{2}{|c|}{$\begin{array}{c}\text { Unstandardized } \\
\text { Coefficients }\end{array}$} & \multirow{2}{*}{$\begin{array}{c}\text { Standardize } \\
d \\
\text { Coefficients } \\
\text { Beta }\end{array}$} & \multirow[b]{2}{*}{$\mathrm{T}$} & \multirow[b]{2}{*}{ Sig. } \\
\hline & $\mathrm{B}$ & Std. Error & & & \\
\hline $\begin{array}{ll}1 & \text { (Constant) }\end{array}$ & 3.720 & 2.895 & & 1.285 & .202 \\
\hline Atraksi & 1.142 & .234 & .410 & 4.872 & .000 \\
\hline Aksesibilitas & .417 & .205 & .197 & 2.033 & .045 \\
\hline Amenitas & .310 & .114 & .277 & 2.733 & .007 \\
\hline $\begin{array}{l}\text { Kualitas } \\
\text { Pelayanan }\end{array}$ & .058 & .119 & .051 & .487 & .628 \\
\hline
\end{tabular}

Sumber : Hasil Pengolahan Data SPSS (versi 25), 2021 
Berdasarkan analisis data dengan menggunakan SPSS 25, maka diperoleh hasil persamaan regresi sebagai berikut :

$$
\mathrm{Y}=\mathbf{3 , 7 2 0}+\mathbf{1 . 1 4 2}+\mathbf{0 , 4 1 7}+\mathbf{0 , 3 1 0}+\mathbf{0 , 0 5 8}+\mathrm{e}
$$

Persamaan regresi diatas memperlihatkan hubungan antara variabel independen dengan variabel dependen secara parsial, dari persamaan tersebut.

\section{Uji Kolerasi Berganda}

\section{Tabel 4. Kolerasi Berganda}

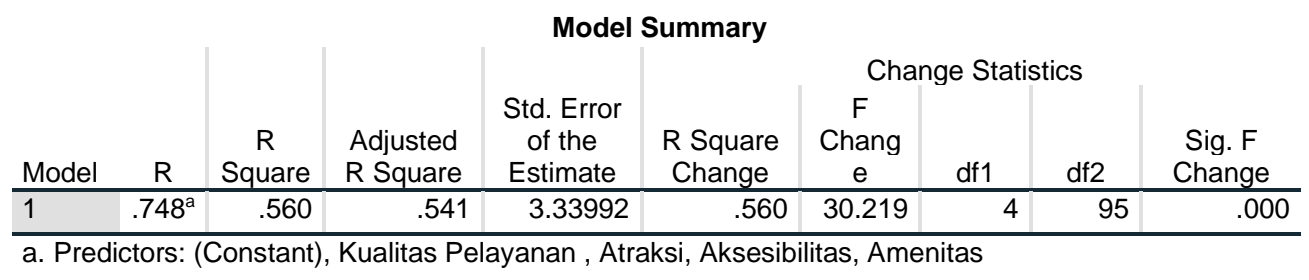

Sumber : Hasil Pengolahan Data SPSS (versi 25), 2021

Korelasi antar variabel dan nilai $r=0,748$ artinya terdapat hubungan yang kuat antara variabel Atraksi, Aksesibilitas, Amenitas, Kualitas Pelayanan dan Minat Kunjungan Ulang Wisatawan.

\section{Uji Koefisien Determinasi}

\section{Tabel 5. Kofisien Determinasi}

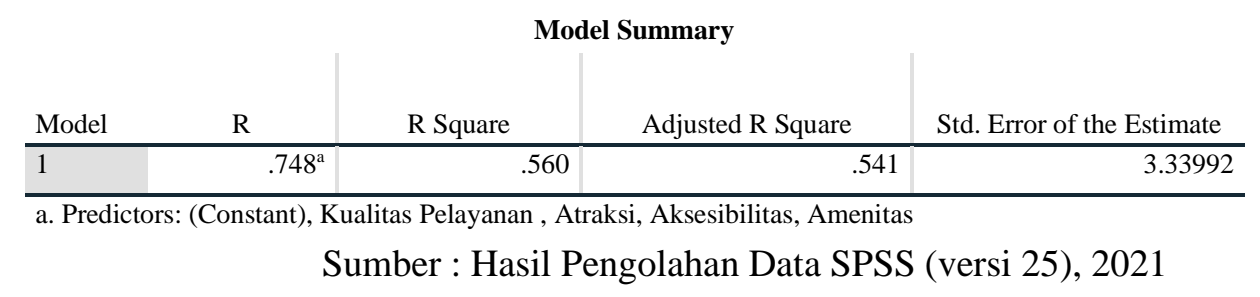

Dari tabel 7 dapat dilihat bahwa nilai Adjusted R Quare (koefisien determinasi) sebesar 0,541. Hal ini berarti kemampuan variabel independen $(\mathrm{X})$ terhadap variabel dependen (Y) sebesar $54,1 \%$ secara simultan.

\section{Uji Hipotesis}

1. Uji-t

\section{Tabel 6. Uji-t}

\begin{tabular}{|c|c|c|c|c|c|c|}
\hline \multicolumn{7}{|c|}{ Coefficients $^{a}$} \\
\hline & & $\begin{array}{r}\text { Uns } \\
\mathrm{C}\end{array}$ & $\begin{array}{l}\text { ardized } \\
\text { iients }\end{array}$ & $\begin{array}{l}\text { Standardized } \\
\text { Coefficients }\end{array}$ & & \\
\hline \multicolumn{2}{|c|}{ Model } & B & Std. Error & Beta & $t$ & Sig. \\
\hline \multirow[t]{5}{*}{1} & (Constant) & 3.720 & 2.895 & & 1.285 & .202 \\
\hline & Atraksi & 1.142 & .234 & .410 & 4.872 & .000 \\
\hline & Aksesibilitas & .417 & .205 & .197 & 2.033 & .045 \\
\hline & Amenitas & .310 & .114 & .277 & 2.733 & .007 \\
\hline & Kualitas Pelayanan & .058 & .119 & .051 & .487 & .628 \\
\hline
\end{tabular}


Sumber : Hasil Pengolahan Data SPSS (versi 25), 2021

a. Pengaruh Variabel Atraksi Terhadap Minat Kunjungan Ulang Wisatawan $\left(\mathrm{H}_{1}\right)$

Variabel atraksi $\left(\mathrm{X}_{1}\right)$, berpengaruh secara positif dan signikan terhadap Minat Kunjungan Ulang Wisatawan. Hal ini terlihat dari signifikan atraksi $\left(\mathrm{X}_{1}\right) 0,000<0,05$

dan nilai $\mathrm{t}_{\text {tabel }}=\mathrm{t}(\mathrm{a} / 2 ; \mathrm{n}-\mathrm{k}-1=\mathrm{t}(0,05 / 2 ; 100-4-1)=(0,025 ; 95)=1.98525$. Berarti nilai $\mathrm{t}_{\text {hitung }}$ lebih besar dari $\mathrm{t}_{\text {tabel }}(4.872>1.98525)$, maka $\mathrm{H}_{0}$ ditolak dan $\mathrm{H}_{1}$ diterima. Sehingga hipotesis yang berbunyi terdapat pengaruh atraksi terhadap Minat Kunjungan Ulang Wisatawan secara parsial diterima.

b. Pengaruh Variabel Aksesibilitas Terhadap Minat Kunjungan Ulang Wisatawan $\left(\mathrm{H}_{2}\right)$ Variabel aksesibilitas $\left(\mathrm{X}_{2}\right)$, berpengaruh secara positif dan signikan terhadap Minat Kunjungan Ulang Wisatawan. Hal ini terlihat dari signifikan atraksi $\left(\mathrm{X}_{2}\right)$ 0,045 $<0,05$ dan nilai tabel $=\mathrm{t}(\mathrm{a} / 2 ; \mathrm{n}-\mathrm{k}-1=\mathrm{t}(0,05 / 2 ; 100-4-1)=(0,025 ; 95)=1.98525$. Berartinilai thitung lebih besar dari $\mathrm{t}_{\text {tabel }}(2.033>1.98525)$, maka $\mathrm{H}_{0}$ ditolak dan $\mathrm{H}_{2}$ diterima. Sehingga hipotesis yang berbunyi terdapat pengaruh aksesibilitas terhadap Minat Kunjungan Ulang Wisatawan secara parsial diterima.

c. Pengaruh Variabel Amenitas Terhadap Minat Kunjungan Ulang Wisatawan $\left(\mathrm{H}_{3}\right)$

Variabel amenitas $\left(\mathrm{X}_{3}\right)$, berpengaruh secara positif dan signikan terhadap Minat Kunjungan Ulang Wisatawan. Hal ini terlihat dari signifikan atraksi $\left(\mathrm{X}_{3}\right) 0,007<0,05$ dan nilai $\mathrm{t}_{\text {tabel }}=\mathrm{t}(\mathrm{a} / 2 ; \mathrm{n}-\mathrm{k}-1=\mathrm{t}(0,05 / 2 ; 100-4-1)=(0,025 ; 95)=1.98525$. Berarti nilai $t_{\text {hitung }}$ lebih besar dari $\mathrm{t}_{\text {tabel }}(2.733>1.98525)$, maka $\mathrm{H}_{0}$ ditolak dan $\mathrm{H}_{3}$ diterima. Sehingga hipotesis yang berbunyi terdapat pengaruh amenitas terhadap Minat Kunjungan Ulang Wisatawan secara parsial diterima.

d. Pengaruh Variabel Kualitas Pelayanan Terhadap Minat Kunjungan Ulang Wisatawan $\left(\mathrm{H}_{4}\right)$ Variabel Kualitas Pelayanan $\left(\mathrm{X}_{4}\right)$, tidak berpengaruh dan tidak signikan terhadap Minat Kunjungan Ulang Wisatawan. Hal ini terlihat dari signifikan Kualitas Pelayanan $\left(\mathrm{X}_{4}\right)$ 0,628 $>0,05$ dan nilai $\mathrm{t}_{\text {tabel }}=\mathrm{t}(\mathrm{a} / 2 ; \mathrm{n}-\mathrm{k}-1=\mathrm{t}(0,05 / 2 ; 100-4-1)=(0,025 ; 95)=1.98525$. Berarti nilai thitung lebih besar dari tabel $(0,487<1.98525)$, maka $\mathrm{H}_{0}$ diterima dan $\mathrm{H}_{4}$ ditolak. Sehingga hipotesis yang berbunyi tidak terdapat pengaruh atraksi terhadap Minat Kunjungan Ulang Wisatawan secara parsial tidak diterima.

2. Uji-f

\section{Tabel 7 Uji-f}

3. ANOVA $^{\mathrm{a}}$

\begin{tabular}{|c|c|c|c|c|c|c|}
\hline Model & & Sum of Squares & $d f$ & Mean Square & $\mathrm{F}$ & Sig. \\
\hline \multirow[t]{3}{*}{1} & Regression & 1348.380 & 4 & 337.095 & 30.219 & $.000^{\mathrm{b}}$ \\
\hline & Residual & 1059.730 & 95 & 11.155 & & \\
\hline & Total & 2408.110 & 99 & & & \\
\hline
\end{tabular}

Sumber : Hasil Pengolahan Data SPSS (versi 25), 2021

Berdasarkan hasil pengujian pada tabel 9 dapat dilihat pada nilai $F_{\text {hitung }}$ sebesar 30,219 dengan nilai $F_{\text {tabel }}$ adalah 2,47 sehingga nila $F_{\text {hitung }}>F_{\text {tabel }}$ atau 30,219 > 2,47, dan tingkat signifikan 0,000 $<$ 0,05 maka $\mathrm{H}_{0}$ ditolak dan $\mathrm{H}_{1}$ diterima, dapat disimpulkan bahwa variabel atraksi $\left(\mathrm{X}_{1}\right)$, aksesibilitas $\left(\mathrm{X}_{2}\right)$, amenitas $\left(\mathrm{X}_{3}\right)$, kualitas pelayanan $\left(\mathrm{X}_{4}\right)$, secara bersamaan berpengaruh signifikan 
terhadap minat kunjungan ulang wisatawan di Pulau Kumala Kabupaten Kutai Kartanegara.

\section{Pembahasan}

\section{Pengaruh Atraksi terhadap Minat Kunjungan Ulang Wisatawan di Pulau Kumala}

Berdasarkan hasil Uji parsial (t) membuktikan bahwa variabel Atraksi (X1) secara parsial berpengaruh positif dan signifikan terhadap variabel Minat Kunjungan Ulang Wisatawan (Y),

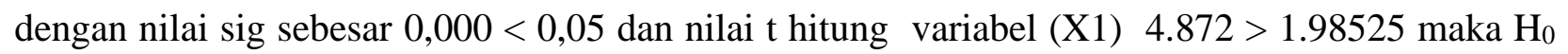
ditolak dan $\mathrm{H}_{1}$ diterima. Sehingga hipotesis yang menyatakan Atraksi tidak berpengaruh signifikan terhadap Minat Kunjungan Ulang Wisatawan tidak diterima dan hipotesis yang menyatakan Atraksi berpengaruh signifikan terhadap Minat Kunjungan Ulang Wisatawan diterima.

Penelitian ini sejalan dengan penelitian yang dilakukan oleh (Ramadhani et al., 2021), dari hasil penelitian dari variabel atraksi memiliki nilai signifikan $0,000<0,05$ yang dapat disimpulkan variabel atraksi memiliki pengaruh siginifikan terhadap minat kunjungan ulang ke Bukit Siguntang.

Menurut Swarbrooke atraksi adalah komponen terpenting dalam sistem pariwisata yang merupakan motivasi utama wisatawan melakukan suatu perjalanan (Oktaviani et al., 2018). Destinasi wisata Pulau Kumala memiliki atraksi wisata buatan yang bisa dinikmati dan wisatawan dapat melihat arsitektur bangunan yang indah dan menarik (what to see). Selain itu Pulau Kumala mempunyai atraksi wisata yang dapat dilakukan (what to do), yaitu menggunakan transportasi sepeda, sepeda motor listrik, dan kereta mini untuk berkeliling di daerah destinasi wisata dan mengabdikan momen dengan cara foto bersama keluarga/teman di lokasi foto yang menarik di Pulau Kumala.

Responden penelitian ini mengungkapkan bahwa variabel atraksi mempengaruhi wisatawan dalam minat kunjungan ke Pulau Kumala. Ini berarti atraksi wisata yang disediakan dapat dinikmati dan menarik wisatawan untuk minat berkunjung ulang ke Pulau Kumala.

\section{Pengaruh Aksesibilitas terhadap Minat Kunjungan Ulang Wisatawan di Pulau Kumala}

Berdasarkan hasil Uji parsial (t) membuktikan bahwa variabel Aksesibilitas (X2) secara parsial berpengaruh positif dan signifikan terhadap variabel Minat Kunjungan Ulang Wisatawan (Y), dengan nilai sig sebesar 0,045 < 0,05 dan nilai thitung variabel (X2) $2.033>1.98525$, maka $\mathrm{H}_{0}$ ditolak dan $\mathrm{H}_{2}$ diterima. Sehingga hipotesis yang menyatakan Aksesibilitas tidak berpengaruh signifikan terhadap Minat Kunjungan Ulang Wisatawan tidak diterima dan hipotesis yang menyatakan Aksesibilitas berpengaruh signifikan terhadap Minat Kunjungan Ulang Wisatawan diterima.

Penelitian ini sejalan dengan penelitian yang dilakukan oleh (Aso et al., 2020) yang memiliki hasil uji parsial variabel aksesibilitas, dengan nilai signifikan sebesar 0,000 $<0,05$ maka dapat simpulkan hasil uji parsial variabel aksesibilitas memiliki pengaruh positif dan signifikan terhadap minat kunjungan wisatawan di Kampung Adat Tutubhada.

Menurut Medlik, menjelaskan bahwa accesable dimaksudkan agar wisatawan domestik dan mancanegara dapat dengan mudah dalam pencapaian tujuan ke tempat wisata (Octaviany, 2016). Pulau Kumala mempunyai akses informasi penunjuk arah menuju ke Pulau Kumala dan ada signal telekomunikasi yang baik. Pulau kumala memiliki akses kondisi jalan menuju ke Pulau Kumala mudah dan aman di jangkau. 
Responden dalam penelitian ini mengungkapkan bahwa variabel aksesibilitas mempengaruhi wisatawan dalam minat kunjungan ke Pulau Kumala. Lokasi tidak jauh dan aman dikunjungi wisatawan, serta akses informasi yang cukup baik, menjadikan wisatawan untuk untuk minat berkunjung ke Pulau Kumala.

\section{Pengaruh Amenitas terhadap Minat Kunjungan Ulang Wisatawan di Pulau Kumala}

Berdasarkan hasil Uji parsial (t) membuktikan bahwa variabel Amenitas (X3) secara parsial berpengaruh positif dan signifikan terhadap variabel Minat Kunjungan Ulang Wisatawan (Y), dengan nilai sig sebesar $0,007<0,05$ dan nilai t hitung variabel (X3) $2.733>1.98525$, maka $_{0}$ ditolak dan $\mathrm{H}_{3}$ diterima. Sehingga hipotesis yang menyatakan Amenitas tidak berpengaruh signifikan terhadap Minat Kunjungan Ulang Wisatawan tidak diterima dan hipotesis yang menyatakan Amenitas berpengaruh signifikan terhadap Minat Kunjungan Ulang Wisatawan diterima.

Penelitian ini sejalan dengan penelitian yang dilakukan oleh (Rossadi \& Widayati, 2018) yang memiliki hasil uji parsial variabel amenitas yang memiliki pengaruh positif dan signifikan terhadap minat kunjungan wisatawan ke wahana air Balong Waterpark yang mmiliki nilai signifikan sebesar $0,001<0,05$.

Menurut Oka A. Yoeti, amenitas adalah fasilitas yang dimiliki daerah tujuan wisata, meliputi akomodasi, usaha pengolahan makanan, transportasi, rekreasi dan lain-lain (Devia \& Diyah Setiyorini, 2012). Pulau Kumala memiliki amenitas/ fasilitas yang dapat memenuhi kebutuhan wisatawan dengan semua jenis transportasi bisa memasuki daerah destinasi wisata. Pulau Kumala menyediakan tempat makan minum, tempat parkir luas, tempat oleh-oleh, toilet, tempat ibadah, dan papan informasi

Responden dalam penelitian ini mengungkapkan bahwa variabel amenitas mempengaruhi wisatawan dalam minat kunjungan ulang ke Pulau Kumala. Semua transportasi bisa memasuki daerah destinasi wisata, lahan parkir yang luas, papan informasi cukup jelas menjadikan wisatawan untuk minat berkunjung ulang ke Pulau Kumala.

\section{Pengaruh Kualitas Pelayanan terhadap Minat Kunjungan Ulang Wisatawan di Pulau Kumala.}

Berdasarkan hasil Uji parsial (t) membuktikan bahwa variabel Kualitas Pelayanan (X4) secara parsial berpengaruh positif dan tidak signifikan terhadap variabel Minat Kunjungan Ulang Wisatawan (Y), dengan nilai sig sebesar 0,628 > 0,05 dan nilai thitung variabel (X4) $0,487<$ 1.98525, maka $\mathrm{H}_{0}$ diterima dan $\mathrm{H}_{4}$ ditolak. Sehingga hipotesis yang menyatakan Kualitas Pelayanan tidak berpengaruh signifikan terhadap Minat Kunjungan Ulang Wisatawan diterima dan hipotesis yang menyatakan Kualitas Pelayanan berpengaruh signifikan terhadap Minat Kunjungan Ulang Wisatawan tidak diterima. Penelitian ini sejalan dengan penelitian yang dilakukan oleh (Nikmatul Khusna, 2018) yang menyatakan bahwa Kualitas Pelayanan berpengaruh positif dan tidak signifikan terhadap Minat Kunjungan Ulang Wisatawan, karena nilai signifikan kualitas pelayanan memiliki nilai sebesar $0,928>0,05$.

Menurut Fitzsimmons bersaudara, menjelaskan bahwa kualitas pelayanan adalah sesuatu yang kompleks, dan tamu akan menilai kualitas pelayanan melalui lima prinsip dimensi pelayanan 
yaitu relibilitas, daya tanggap, jaminan, empati dan bukti langsung (Sarifuddin \& Isra, 2019). Kualitas Pelayanan di Pulau Kumala berupa petugas melayani wisatawan, mengatasi keluhan wisatawan, memberikan informasi harga tiket masuk dan jasa pelayanan, melayani dengan ramah dan sopan santun, serta penampilan pakaian petugas rapi dan sopan.

Responden dalam penelitian ini mengungkapkan bahwa variabel kualitas pelayanan tidak mempengaruhi wisatawan dalam minat kunjungan ke Pulau Kumala. Ini berarti petugas melayani wisatawan, memberi informasi yang ada di destinasi wisata, dan penawaran jasa pelayanan yang ada di Pulau Kumala tidak mempengaruhi Minat Kunjungan Ulang Wisatawan ke Pulau Kumala.

\section{Pengaruh Atraksi, Aksesibilitas, Amenitas, dan Kualitas Pelayanan Terhadap Minat Kunjungan Ulang Wisatawan di Pulau Kumala.}

Berdasarkan hasil uji-f membuktikan bahwa variabel (X1) Atraksi, variabel (X2) Aksesibilitas, variabel (X3) Amenitas, dan variabel Kualitas Pelayanan berpengaruh positif dan signifikan terhadap Minat Kunjungan Ulang Wisatawan, dengan nilai signifikan 0,000 < 0,05 dan nilai $\mathrm{F}$ hitung 30,219 > 2,47, maka $\mathrm{H}_{0}$ ditolak dan $\mathrm{H}_{5}$ diterima, dapat disimpulkan bahwa variabel atraksi $\left(\mathrm{X}_{1}\right)$, aksesibilitas $\left(\mathrm{X}_{2}\right)$, amenitas $\left(\mathrm{X}_{3}\right)$, kualitas pelayanan $\left(\mathrm{X}_{4}\right)$, secara bersamaan berpengaruh signifikan terhadap minat kunjungan ulang wisatawan di Pulau Kumala Kabupaten Kutai Kartanegara.. Dengan demikian dapat dijelaskan bahwa semakin menarik atraksi, memadainya aksesibilitas, amenitas dan tingkat kualitas pelayanan yang sangat baik maka Minat Kunjungan Ulang Wisatawan di Pulau Kumala akan meningkat dan wisatawan akan merasa puas.

Penelitian ini sejalan dengan penelitian yang dilakukan oleh (Ramadhani et al., 2021), yang memiliki nilai (f hitung) 55,056 > 2,47 (f tabel) dengan nilai signifikan 0,000>0,05 dapat disimpulkan pada variabel atraksi wisata, amenitas, aksesibilitas dan ancillary service secara simultan terhadap minat kunjungan ulang wisatawan.

Menurut Smith, 1988 (dalam Pitana, 2005) mengklasifikasikan berbagai barang dan jasa yang harus disediakan oleh Daya Tarik Wisata menjadi enam kelompok besar, yaitu, Transportation, Travel services, Accommodation, Food services, Activities and attractions (recreation culture/entertainment), dan Retail goods.

Pulau Kumala memiliki Atraksi wisata menarik dan unik, akses informasi cukup baik, kondisi jalan yang aman dan lokasi tidak jauh untuk dijangkau, memiliki amenitas yang baik untuk memenuhi kebutuhan wisatawan, dan kualitas pelayanan dari petugas cukup baik mengatasi solusi wisatawan maupun menjelaskan informasi di Pulau Kumala.

\section{SIMPULAN}

Variabel Atraksi secara parsial berpengaruh positif dan signifikan terhadap Minat Kunjungan Ulang Wisatawan. Variabel Aksesibilitas secara parsial berpengaruh positif dan signifikan terhadap Minat Kunjungan Ulang Wisatawan. Variabel Amenitas secara parsial berpengaruh positif dan signifikan terhadap Minat Kunjungan Ulang Wisatawan. Variabel Kualitas Pelayanan secara parsial tidak berpengaruh signifikan terhadap Minat Kunjungan Ulang Wisatawan. Variabel Atraksi, Aksesibilitas, Amenitas, dan Kualitas Pelayanan secara simultan berpengaruh positif dan signifikan terhadap Minat Kunjungan Ulang Wisatawan 


\section{BIBLIOGRAFI}

Aso, M. T., Roedjinandari, N., Rachmadian, A., Setioko, D., \& Sutanto, D. H. (2020). Pengaruh Daya Tarik Wisata dan Aksesibilitas terhadap Minat Kunjungan Wisatawan di Kampung Adat $\begin{array}{lllll}\text { Tutubhada Kabupaten Nagekeo. Jurnal Pariwisata, } & 2(2),\end{array}$ https://www.researchgate.net/profile/Muhammad-Danang-

Setioko/publication/350992513_PENGARUH_DAYA_TARIK_WISATA_DAN_AKSESIB ILITAS_TERHADAP_MINAT_KUNJUNGAN_WISATAWAN_DI_KAMPUNG_ADAT_ TUTUBHADA_KABUPATEN_NAGEKEO/links/607e4c2f8ea909241e105a61/PENGARU H-DAYA-TAR

Devia, K., \& Diyah Setiyorini, G. H. (2012). Pengaruh Revitalisasi Produk Wisata Terhadap Preferensi Mengunjungilembah Bougenville Resort (Survei Pada Pengunjung Lembah Bougenville Resort Kecamatan Lembang Kabupaten Bandung Barat). THE) Journal, II(2), 2012-2387.

Fajri, I. (2018). Strategi Peningkatan Penjualan Makanan Tradisional Sunda Melalui Daya Tarik Produk Wisata Kuliner di The Jayakarta Bandung Suite Hotel \& Spa. THE Journal : Tourism and Hospitality Essentials Journal, 8(1), 45. https://doi.org/10.17509/thej.v8i1.11689

Gofur, A. (2019). PENGARUH KUALITAS PELAYANAN DAN HARGA TERHADAP KEPUASAN PELANGGAN. Riset Manajemen Dan Bisnis (JRMB) Fakultaskultas Ekonomi UNIAT, 4(1), 37-44. http://jrmb.ejournal-feuniat.net/index.php/JRMB

Guspul, A. (2014). Pengaruh Kualitas Pelayanan dan Kepercayaan Terhadap Kepuasan Nasabah (Studi Kasus Pada Nasabah Kospin Jasa Cabang Wonosobo). Jurnal PPKM UNSIQ I, 1(1), 40-54.

Isabari, A. S., Amani, H., \& Sagita, B. H. (2021). IMPROVEMENT SERVICE QUALITY USING FUZZY-SERVQUAL APPROACH AND IMPORTANCE PERFORMANCE ANALYSIS TECHNIQUE ON THE PANGANDARAN Target Realisasi Pengunjung Pangandaran. 8(5), 8627-8637.

Kurniansah, R. (2016). Persepsi Dan Ekspektasi Wisatawan Terhadap Komponen Destinasi Wisata Lakey-Hu'U, Kabupaten Dompu. Jurnal Master Pariwisata (JUMPA), January 1970. https://doi.org/10.24843/jumpa.2016.v03.i01.p06

Octaviany, V. (2016). Pengaruh Kualitas Produk Pariwisata Terhadap Keputusan Berkunjung Di Bale Seni Barli-Kota Baru Parahyangan. Tourism Scientific Journal, 1(2), 184. https://doi.org/10.32659/tsj.v1i2.11

Oktaviani, F. D., Yusup, P. M., \& Khadijah, U. L. S. (2018). Penggunaan layanan open library dalam memenuhi kebutuhan informasi mahasiswa Telkom University. Jurnal Kajian Informasi Dan Perpustakaan, 5(2), 127. https://doi.org/10.24198/jkip.v5i2.12856

Ramadhani, S. A., Setiawan, H., \& Rini. (2021). Analisis Pengaruh Atraksi Wisata, dan Ancillary Service terhadap Minat Kunjung Ulang pada Objek Wisata Bukit Siguntang. Jurnal Terapan Ilmu Ekonomi, Manajemen Dan Bisnis, 1(3), 124-133. http://jurnal.polsri.ac.id/index.php/jtiemb

Rossadi, L. N., \& Widayati, E. (2018). Pengaruh Aksesibilitas, Amenitas, Dan Atraksi Wisata Terhadap Minat Kunjungan Wisatawan Ke Wahana Air Balong Waterpark Bantul Daerah Istimewa Yogyakarta. Journal of Tourism and Economic, 1(2), 109-116. https://doi.org/10.36594/jtec.v1i2.27

Sarifuddin, \& Isra, M. (2019). Pengaruh Kualitas Layanan Terhadap Kepuasan Pelanggan pada Kentucky Fried Chicken Cabang Palu Grand Mall. Jemma $\mid$ Jurnal of Economic, Management and Accounting, 2(4), 77-88. 